\title{
Maty słownik gwar polskich Pod red. Jadwigi Wronicz Wydawnictwo LEXIS, Kraków 2009, ss. 366
}

Z końcem pierwszej dekady XXI wieku zespół krakowskich dialektologów opublikował Mały słownik gwar polskich. Brak takiej pozycji leksykograficznej od dawna odczuwali wszyscy zainteresowani regionalnymi odmianami polszczyzny i podkreślali to na wszelkich konferencjach poświęconych różnym działaniom $\mathrm{w}$ zakresie dialektologii. Potrzebę wydania profesjonalnie opracowanego słownika odczuwano szczególnie w obliczu coraz liczniej pojawiających się rozmaitych słowników i słowniczków lokalnej mowy, redagowanych przez miłośników lokalnych kultur. Wartość tych publikacji jest na ogół mierna - mimo że sama inicjatywa godna pochwały - bowiem ich autorzy kierowali się w swoich pracach, i owszem, sentymentem do swoich "małych ojczyzn”, ale nie profesjonalną wiedzą leksykograficzną. Owe lokalne słowniczki gwarowe skierowane były poza tym do małego kręgu odbiorców. Nie przekraczały bowiem zazwyczaj granic gmin, w których powstały ${ }^{1}$. Innym rodzajem słowników regionalnych, o znacznie szerszym kręgu odbiorców, są słowniczki gromadzone na stronach internetowych. Ale i tu mamy w głównej mierze do czynienia $\mathrm{z}$ mało uporządkowanym zbiorem nazw, wyrażeń, frazeologizmów itp., wśród których, oprócz rzeczywistych regionalizmów, znajdziemy takie formy, które wpisującemu/wpisującym wydawały się

1 Dobrym przykładem niech będzie tu: Słownik języka prostego: zrealizowany przez Grupe Inicjatyw Młodzieżowych w ramach projektu "Babcine przepisy na młodość”, Dąbrowa Białostocka 2007, s. 32. Inną publikacją, zakrojoną na trochę szerszą skalę, ale również kierowaną lokalnym patriotyzmem jest: Jana Bacewicza, Gwara i kuchnia Suwalszczyzny, Suwałki 2007, s. 140. Książeczka ta pełni jednak bardziej funkcję przewodnika po kulturze regionu suwalskiego, niż zbioru nazw gwarowych. Słowniczek wypełnia w niej zaledwie 34 strony. 
regionalne, chociaż nimi nie są. Mały słownik gwar polskich (2009) cieszy tym bardziej, że od jego poprzednika Słownika gwar polskich Jana Karłowicza (t. 1-6, 1900-1911) mija właśnie cały wiek.

Słownik opracował Zespół Zakładu Dialektologii Instytutu Języka Polskiego Polskiej Akademii Nauk w Krakowie w osabach: prof. Jadwiga Wronicz - redakcja, prof. Jerzy Reichan, dr Renata Kucharczyk, mgr Anna Niezabitowska, mgr Maria Tokarz i mgr Wiktoria Wójcicka. Podstawą materiałową w pracach nad Słownikiem był ogromny zbiór fiszek (ok. 2.400.000), będących w posiadaniu archiwum IJP PAN w Krakowie. Celem publikacji - co podkreśla we Wstępie prof. J. Wronicz było udostępnienie wszystkim zainteresowanym (nauczycielom j. polskiego, pracownikom regionalnych placówek kultury, pisarzom, dziennikarzom, miłośnikom kultury ludowej) materiału leksykalnego obrazującego mowę mieszkańców wsi w poszczególnych wielkich dialektologicznych regionach kraju - mazowieckim, małopolskim, wielkopolskim, śląskim i kaszubskim².

W Słowniku zgromadzono ponad dziesięć tysięcy haseł. Wszystkie opatrzono tylko znaczeniami gwarowymi, toteż Autorzy zrezygnowali z umieszczenia obok wybranych haseł, typowych dla słowników ogólnych, kwalifikatorów: gwarowy, potoczny czy dawny. Doboru zamieszczonych w słowniku nazw dokonano ze szczególną starannością i wrażliwością na dokonujące się $\mathrm{w}$ gwarach procesy zmian, np. przesunięcie się określonego słownictwa $\mathrm{z}$ zasobu polszczyzny ogólnej do sfery nazw o charakterze potocznym, dawnym. Taką formą jest np. nazwa napiętek 'obcas', która w Słowniku języka polskiego pod red. W. Doroszewskiego potraktowana jest jeszcze jako nazwa ogólna, ale dziś bez wątpienia odczuwa się ją już jako dawnq, przestarzałq (gwarowq). Zainteresowani sferą polszczyzny ludowej znajdą wśród haseł w omawianym Słowniku oprócz gwarowych innowacji znaczeniowych, także takie, których formy różnią się od ogólnych pod względem fonetycznym, np. wiskup 'biskup', czy systemowym, np. zdrzadło i zrzadło 'lustro'.

Ważnym i cennym novum tego Słownika, w stosunku do wcześniejszych, jest zastosowanie, wprowadzonego przez prof. Józefa Kąsia

2 Kaszubszczyzna dopiero od 2005 roku cieszy się statusem języka regionalnego. W ogromnych zasobach literatury dialektologicznej, wydanej przed tą datą, obecny język kaszubski traktowany jest jako jeden z dialektów języka polskiego. Autorzy Słownika, korzystając ze zbiorów gromadzonych od początków wieku XIX do dziś, formy kaszubskie odnotowują zatem jako część wielkiego zespołu gwar polskich. 
w Słowniku gwary orawskiej, uproszczonego zapisu cytatów z wypowiedzi użytkowników poszczególnych gwar. Owo novum polega na wdrożeniu pisowni ogólnopolskiej $\mathrm{w}$ miejsce do niedawna stosowanej pisowni fonetycznej, zrozumiałej tylko dla wyspecjalizowanych w jej czytaniu dialektologów. Innowacja ta umożliwia poszerzenie kręgu odbiorców Słownika. Publikacja pozwala każdemu, kto po nią sięgnie (bez względu na poziom wiedzy lingwistycznej), podziwiać bogactwo polszczyzny regionalnej. Staje się tym samym ciekawą lekturą nie tylko dla wtajemniczonych. Z łatwością skorzysta z niej uczeń, student i nauczyciel kierunków innych niż polonistyczne, animator kultury ludowej, a także i sam przedstawiciel prezentowanej w Słowniku gwary. Porównanie zapisu fonetycznego i ogólnego na pewno $\mathrm{w}$ oczach przeciętnego odbiorcy będzie przemawiało za tym drugim:

Čynok to pšetak žatk'i na čyny - zapis fonetyczny.

Trzyniok to pszetak rzádki na trzyny - zapis w Słowniku. [Trzyniok 'sito'.]

Słownik powstał zatem z myślą o różnorodnym odbiorcy. Zgromadzono $\mathrm{w}$ nim najbardziej charakterystyczne dla poszczególnych gwar formy wyrazowe. Hasła zostały ułożone w porządku alfabetycznym. Ułatwia to odnalezienie konkretnej nazwy gwarowej. Każde hasło w pierwszej kolejności opatrzone jest znaczeniem, po nim występuje z użytym hasłem cytowana wypowiedź autochtona, następnie lokalizacja (miejsce występowania formy gwarowej) oraz inicjały Autora, który opracował dane hasło, np.:

abo 1. 'albo': Dzisiej abo jutro przijedzie Jędrysek lubl: Śl, Mp, Maz, Wp. Pom pd.

2. 'czy': Idzies abo nie idzies Samocice dąb-tar; Śl, Mp. AC

bajstruk, bastruk 'dziecko nieślubne; bękart': Wszystkie wiedzo, że Waćka jest bajstruk Łopatowszczyzna [Wilno Lit]; Maz wsch, Kresy. JR

powszedek 'dzień powszedni': Jak sie robi, to je powszedek, a jak sie śwéntuje, to je niedziela Obręb sierp; Maz pn. JR

W dobie Internetu i cyfrowych nośników pamięci, wśród zalewu rynku księgarskiego mnóstwem najdziwniejszych pozycji leksykograficznych ${ }^{3}$ "profesjonalnie wykonany i przystępny dla czytelników niemających teoretycznego przygotowania dialektologicznego" 4 Mały słownik

3 Wystarczy wejść na stronę internetową poświęconą słownikom, żeby przekonać się o ich liczebności i różnorodności.

$4 \mathrm{Z}$ recenzji prof. Józefa Kąsia. 
gwar polskich pod red. Jadwigi Wronicz bez wątpienia można zaliczyć do wydawniczego wydarzenia. Wypuszczony na rynek $\mathrm{w}$ tradycyjnej formie książkowej powinien trafić nie tylko na półki uniwersyteckich bibliotek, ale także do rąk tych, którzy umożliwili zbudowanie tak potrzebnego, w czasach globalizacyjnych procesów, pomostu między przeszłością i przyszłością języka polskiego. Dla tych odbiorców Słownik będzie wyrazem wielkiego uznania dla ich codziennej dbałości o to, by kultura minionych pokoleń równie pomyślnie służyła obecnym i przyszłym generacjom.

Natalia Szydłowska

Uniwersytet w Białymstoku 